\title{
The Difference of Influence of Learning Methods and Coordination Eye-Hand Against The Results of The Study Lay-Up Shoot on Student PKO FIK UNIMED 2018
}

\author{
Ibrahim Wiyaka ${ }^{1}$, Nustan Hasibuan ${ }^{2}$ \\ \{Ibrahimwiyaka10@gmail.com ${ }^{1}$ \} \\ Department of Sport Science, State University of Medan, Medan, Indonesia ${ }^{1,2}$
}

\begin{abstract}
Lay-up shoot is one type of shot in a basketball game that is used to break through the opponent's defense to shoot closer to the basketball hoop, but not infrequently this shot fails due to eye-hand coordination and leg muscle power that is lacking in players so Mastery of the ball when ending the dribbling and when lifting the ball and repulsion that is not good at shooting causes the ball not to enter the ring. The purpose of this study was to find out (1). Differences in the effect of alternate leg bound and double leg bound learning methods on the learning outcomes of lay-up shoot. (2). Differences in influence between high-eye hand coordination and low eye-hand coordination on learning outcomes from lay-up shoot. (3) Knowing whether there are interactions between learning methods and eye-hand coordination of the learning outcomes of lay-up shoot. Research uses experimental methods. The design of the study was Factorial $2 \times 2$. The population of this study was all FIK Unimed PKO students who took the advanced basketball course. A sample of 70 people were taken with total sampling technique. Research instruments used eye-hand coordination tests and lay up shoot tests. Data analysis techniques used statistical analysis while the calculation used a difference test with Anova Factorial 2 x 2 experiments at a significant level of 5\%. to fulfill the assumptions the results of the research were tested for reliability and prerequisite test analysis. The results showed (1). There are differences in effects between alternate leg bound and double leg bound learning methods on the learning outcomes of lay up shoot. (2). There is a difference in the effect of high-eye hand coordination and low eye-hand coordination on the learning outcomes of lay up shoot, and, (3). There is an interaction between learning methods with eye-hand coordination on the learning outcomes of lay up shoot..
\end{abstract}

Keywords: Learning Method, Eye-Hand Coordination, Lay-up Shoot.

\section{Introduction}

To be able to play well, a player is required to master the basic techniques of playing including; passing, dribbling, pivot and shooting. Shooting (shooting) is very important role, because only with shooting as if the player can enter the ball. Of the many shooting techniques, one of them is the lay up shoot technique. This type of shooting is often done by players to break through the guard and defend the opponent closer to the ring to enter the ball. 
Mistakes during lay up shoots that often occur so that the ball does not enter is; lack of eye coordination with the hand to catch the ball while ending dribbling, unfavorable footsteps cause loss of balance when you want to lift the ball, and lack of foot repulsion, and lack of hand eye coordination when you want to put the ball into the ring.

There are many ways that can be done to improve the ability of learning results of lay up shoot, among others; ability to jump with alternate leg bound and double leg bound training methods, eye hand coordination exercises by throwing the ball into the wall.

To be able to improve the ability to jump can be trained with alternate leg bound and double leg bound learning methods. Both forms of exercise are included in the form of plyometric exercises that aim to increase the explosive power of the leg muscles. because the mechanism of the movement mostly involves muscles in the lower extremities (Car, 2003 in Cahyo et al, 2012). In this exercise the developed are leg and hip power. By altering both limbs especially the work of flexsor and extensor on the thighs and hips. The functional anatomy of alternate leg bound movements includes bounding categories including (1) flexi thighs, which involve the muscles of sartorius, illacus and gracillus, (2) knee extension involving muscles rectus femoris, vastus lateralis, medial and intermedius (quadrisep group), (3) thigh extension, involving the muscles of the femoris biceps, semitendinosus, and seminembranosus (hamstring group) and also involving the maximax gluteus muscles and minimus (gluteus group), (4) flexing the knee and feet, involving the gastrocnemius muscle, (5) adduction and abduction of the thighs, involving the gluteals and adductor longus, brevis, magnus, manimus and hallusis muscles (Hidayat, 2015). Next Double Leg Bound. In this exercise developed the power of the leg and hip muscles, especially gluteals, hamstring, quadriceps, and gastrocnemius. The muscles of the arms and shoulders are also indirectly involved. This exercise has broad applications for various sports that involve jumping / jumping like basketball. The location of the alternate leg bound and double leg bound plyometric training methods is the pliometric training technique in the alternate leg bound using one of the right or left legs, which rejects from behind and the other leg is lifted as far as possible forward and swings both arms from front to back. Whereas in the plyometric training method, double leg bound training techniques jumped upwards and landed as far as possible in front of them using two legs and swung both arms from top to bottom.

In addition to the repulsion capabilities needed in lay up shoots, eye-hand coordination is also needed. Coordination is the ability to combine several movements to achieve a harmonious movement in accordance with the objectives. (Suharno HP, 1981: 29). Another opinion expressed by Bompa (1983: 12), coordination is a complex motor skill necessary for high performance.

Coordination is a complex need for high performance. Furthermore Bompa (1990) added that coordination is a very complex biomotor ability, interconnected with speed, strength, endurance, and flexibility. According to Sanjoto (1999: 9), that coordination is a person's ability to integrate different movements into an effective single movement pattern. So that coordination is the body's ability to combine several elements of the movement into an effective and harmonious movement in accordance with its objectives. 
In performing lay up shoots, it requires the development of maximum power coordination. Coordination must be developed with appropriate, easy and precise movements. To produce better lay up shoot, it is necessary to coordinate the movement of the foot with visuals. Eyehand coordination when performing lay up shoot is an ability in combining visual perception with hand movements into a special motion pattern, which is directing the ball to the target object in the form of a board or ring. A player who does not have a good level of coordination will not produce good and profitable shoot quality in a game.

\section{Research method}

\subsection{Research design}

Table 1. Research Design Factorial 2 x 2

\begin{tabular}{|c|c|l|}
\hline Lye-Hand & & \\
Coordination & $\begin{array}{l}\text { Alternate } \\
\text { Leg Bound } \\
\text { (A1) } 1\end{array}$ & $\begin{array}{l}\text { Double } \\
\text { Leg } \\
\text { Bound } \\
\text { (A2) }\end{array}$ \\
\hline High (B1) & AIB1 & A2B1 \\
\hline Low (B2) & A2B1 & A2B2 \\
\hline
\end{tabular}

\subsection{Population and research sample}

The population in this study is the entire student population is taking advanced basketball courses. While the sample in this study were 70 students (sample total)

\subsection{Research instruments}

a). Eye-Hand Coordination Test

b). Lay Up Shoot Test 
Table 2. Summary of Descriptive Statistics of Learning Outcomes Data Lay

Up Shoot according to the Research Group.

\begin{tabular}{|c|c|c|c|c|c|}
\hline Method & $\begin{array}{l}\text { Eye-Hand } \\
\text { Coordination }\end{array}$ & Statistics & Pre-Test & Post-Test & Enhancement \\
\hline \multirow{6}{*}{$\begin{array}{l}\text { Alternate } \\
\text { Leg } \\
\text { Bound ( } \\
\text { A1) }\end{array}$} & \multirow{3}{*}{ High (B1) } & Total & 908 & 935 & 27 \\
\hline & & Mean & 50.46 & 51.94 & 1.48 \\
\hline & & SD & 1.85 & 2.45 & \\
\hline & \multirow{3}{*}{ Low (B2) } & Total & 814 & 841 & 27 \\
\hline & & Mean & 47.93 & 49.50 & 1.57 \\
\hline & & SD & 5.05 & 2.52 & \\
\hline \multirow{6}{*}{$\begin{array}{l}\text { Double } \\
\text { Leg } \\
\text { Bound ( } \\
\text { A2) }\end{array}$} & \multirow{3}{*}{ High (B1) } & Total & 889 & 906 & 17 \\
\hline & & Mean & 49.42 & 50.36 & 0,94 \\
\hline & & SD & 3.46 & 1.86 & \\
\hline & \multirow{3}{*}{ Low (B2) } & Total & 844 & 860 & 16 \\
\hline & & Mean & 49.61 & 50.61 & 1 \\
\hline & & SD & 3.20 & & \\
\hline
\end{tabular}

Based on the description of the alternate leg bound and double leg bound learning method data and high hand-eye coordination level and low eye-hand coordination, it shows:

1. When compared between groups of students who received treatment for lay-up shoot using the alternate leg bound method with an average increase of 1.54 and a double leg bound average increase of 0.94 , an increase of 0.6 . this means that the alternate leg bound method is better than the double leg bound method. 2 . When compared between groups of students who have a high increase in eye-hand coordination 44 and who have low-level eye-hand coordination 43 .

\section{Result and discussion}

1. The results of the calculation of the hypothesis that there are differences in the effect of the alternate leg bound method with double leg bound on the learning outcomes of lay up shoot for PKO FIK-Unimed students in 2018. Based on the results obtained show that there are differences in the influence between the alternate leg bound method and double leg bound on learning outcomes of shoot lay-p $0.006<\alpha 0.05$.

Learning alternate leg bound and double leg bound is a form of pliometric training that aims to increase the power of leg muscles. Having the explosive power of the leg muscles 
allows the athlete to jump as high as possible as in lay up shoots in a basketball game, with a high jump that makes it easy to insert the ball into the ring.

Plaiometric work is called "stretch reflex" (also called "stretch reflex"), also called "spindle reflex" or "myotatic reflex" (reflex or miotatic reflex spindle). Shaft reflex devices or devices and strain reflexes are components main of the overall nervous system control of body movements. Plyometric exercises are exercises to develop stretch reflex ability in the muscles to produce explosive movements.

The principle of this exercise movement is the change in the motion of both legs, namely the flexor and extensor thighs and hips (Hidayat, 2015). The plyometric alternate leg bound exercise has the same goal as double leg bound, but it is different in the way it is done, where in the alternate leg bound exercise it jumps with one foot swing forward like kicking. Whereas in the double leg bound exercise, jumping forward upwards using extensions on the hips and arm movements to push forward and both legs jump together (Primayanti, 2011).

Based on the purpose of the exercise to increase the leg muscle power to make high jumps, then this exercise is suitable to improve the results of lay up shoots because shoot shoots also require a high jump to approach the ball inserting ring.

When viewed from the specifications of the motion will allow the difference in the results of the lay up shoot. In the alternate leg boundary exercise emphasizes one foot leap forward, while the double leg boundary emphasizes the jump and two foot swing. But if it is associated with lay up shoot techniques that require high jumps and hand swings, the alternate leg bound exercise is better than double leg bound in increasing lay up shoot results because footwork in alternate leg bound exercises is similar to foot repulsion in lay up shoots. .

2. The results of the calculation of the hypothesis which states that there is a difference in influence between high-hand eye coordination and low-hand eye coordination on the learning outcomes of lay up shoot for PKO FIK-Unimed students in 2018. - $p 0.000<\alpha 0.05$.

The findings in this study explain that athletes who have high eye-hand coordination will be able to perform better lay-up shoots than those who have low-eye hand coordination. Students who have high eye-hand coordination allow coordinating the lay up shoot movement to be more effective and efficient and able to steer the target.

Thus it can be said that high-hand eye coordination is very necessary for every basketball player. Based on this, each athlete needs to have high eye-hand coordination to support the ability to shoot up.

3. Interaction Between the Eye Coordship - hands with Learning Outcomes lay up shoots.

The results of the research about the hypothesis that there is an interaction between Mata-hand coordination with the ability to lay up shoot $-\mathrm{p} 0,000<0,05$. Adjustd R Square value of 0.979 means that there is an interaction of $97.9 \%$.

Overall it can be explained that after statistical testing of empirical data obtained from the field it can be said that the proposed eye-hand coordination variable provides an interaction with the ability to lay up shoot.

The level of coordination of a person's motion is a reflection of its ability to carry out a movement smoothly, precisely and efficiently. A person with good coordination is not only able to do a skill perfectly, but also can easily and quickly do movement skills that are still new to him.

Thus, it can be explained the importance of having good eye-hand coordination so that it can improve lay-up shoot. 


\section{Conclusion and suggestions}

\subsection{Conclusion}

1. There is a difference in the effect of alternate leg bound and double leg bound learning methods on learning outcomes of lay up shoot 2 . There is a difference in effect between high eye-hand coordination and low eye-hand coordination on the results of learning lay up shoots. 3. There is an interaction between the lay-up shoot learning method and eye-hand coordination.

\subsection{Suggestions}

1. In an effort to improve the learning outcomes of lay up shoots, in addition to the application of appropriate learning methods must pay attention to the level of eye-hand coordination of students.

2. Teachers and trainers are expected to apply alternate leg bound and double leg bound learning models to improve the learning outcomes of lay up shoots.

\section{References}

[1] Bompa, Tudor O.:. Theory and Methodology Of Training (1990)

[2] Debeque, Lowa: Kendall/Hunt Publishing Company.CP.:. Theory and Methodology of Training. Canada: Kendall/Hunt Publishing Company (1994)

[3] Harsono.:. Coaching dan Aspek-Aspek Psikologis dalam Coaching. Bandung. Tambak Kusuma CV.Nugraha Indah Cahya (1998)

[4] Ismaryati.: Tes dan Pengukuran Olahraga. Surakarta. UNS Press (2006)

[5] Primayanti.: Perbedaan Pengaruh Metode Latihan Plyometrik dan Berbeban Terhadap Peningkatan Kecepatan Smash Bolavoli Ditinjau Dari Kekuatan Otot Lengan.Solo. Universitas Sebelas Maret (2011)

[6] Sajoto.: Pembinaan Kondisi Fisik Dalam Olahraga. Jakarta. Departemen Pendidikan dan Kebudayaan Direktorat Jenderal Pendidikan Tinggi Proyek Pengadaan Buku Pada Lembaga Tenaga Pendidikan (1998)

[7] Sudjana, Nana.:. Penilaian Hasil Proses Belajar Mengajar. Bandung.Suharno, HP. (1981). Ilmu Kepelatihan Olahraga. Bandung. PT. Karya Ilmu (2013)

[8] Sukadiyanto.: Teori dan Metodologi Melatih Fisik. Yogyakarta. UNY. (2002)

[9] Sukmadinata, Syaodih.:. Landasan Psikologi Proses Pendidikan. Bandung. PT. Rosda Karya (2005).

[10] Sumiyarsono, Dedi.: Keterampilan Bola Basket. Yogyakarta. UNY (2002)

[11] Surya, Moh.: Psikologi Pembelajaran dan Pengajaran. Bandung.PPB - IKIP Bandung (1997)

[12]Widhiyanti, Komang Ayu.: Pelatihan Piometrik Alternate Leg Bound dan Double Leg Meningkatkan Daya Ledak Otot Tungkai Pada Siswa Putra Kelas VII SMP NEGERI SUKAWATI Tahun Pelajaran 2012/2013. Sport Fitness Journal Volume. 1 No . 2:19-26 Universitas Udayana (2013) 